УДК 619:614.48:616.98:579.873.21.

(C) 2013

Щербакова Н. С., кандидат ветеринарних наук

Полтавська державна аграрна академія

\title{
ВИЗНАЧЕННЯ БЕЗПЕЧНОСТІ М'ЯСА ПТИЦІ, ХВОРОЇ НА ЕЙМЕРІОЗ
}

\section{Рецензент - кандидат ветеринарних наук І. В. Лавріненко}

Дається оиінка безпеки м'яса курей, хворих на еймеріоз. Наведено дані щзодо визначення токсичності м'яса птиці експрес-методом за допомогою інфузорій Colpoda steinii. Крім того обтрунтовується ветеринарно-санітарна оцінка м'яса хворої на еймеріоз птииі, яка полягає в тому, щзо м'ясо, отримане від хворої птиці з ознаками виснаження, є токсичним, $і$ його треба направляти на технічну утилізацію. Якщчо м'ясо отримане від хворої птииі, але тушка не має ознак виснаження, можна випускати у реалізацію після інактивації методом проварювання упродовж трьох годин у відкритих котлах.

Ключові слова: якість, безпека, ветеринарносанітарна оцінка, еймеріоз, м'ясо птиці, токсичність.

Постановка проблеми. Міжнародні стандарти ставлять жорсткі вимоги до експертної перевірки будь-яких продуктів птахівництва (м’ясо, яйце, меланж, яєчний порошок), які без відповідного сертифікату чи дозволу не допускаються на споживчий ринок і вважаються «потенційно небезпечними». За останні роки в Україні теж помітно поліпшилися методи ветеринарно-санітарної експертизи молока, м'яса та продуктів їх переробки, використання яких дає можливість одержати порівняно повне уявлення про харчову цінність і безпеку даної продукції. Що стосується продуктів птахівництва, то це питання ще недостатньо вивчене, - методи ветеринарно-санітарної експертизи птахопродуктів потребують удосконалення, а за окремих інвазійних хвороб птиці ще не розроблено ветеринарно-санітарної оцінки продуктів убою $[1,5]$.

Аналіз літературних джерел, у яких започатковано розв'язання даної проблеми. Куряче м'ясо - одна 3 найважливіших складових здорового харчування. Джерело білків, що легко засвоюються, вітамінів, амінокислот, мінералів незамінний матеріал для росту й функціонування будь-якого організму, основа профілактики низки захворювань і чудовий смак на додаток - це далеко не повний перелік функцій курячого м'яса в нашому раціоні. У ньому більше білків, аніж у будь-якому іншому виді м'яса, до того ж вміст у ньому жирів не перевищує 10 \%. Останні наукові дослідження довели, що саме м'ясо птиці забезпечує повноцінний баланс білку в організмі серед основної маси населення східноєвропейських країн [2]. Однак у разі, якщо м'ясо одержане від хворої птиці, то воно може містити у своєму складі токсини, що виділяють у процесі своєї життєдіяльності паразитуючі організми. Таке м'ясо є небезпечним для організму людини $[3,5]$.

Мета дослідження. Метою роботи було встановити, чи $є$ небезпечним м'ясо, отримане від птиці, хворої на еймеріоз.

Завдання дослідження - встановити ступінь токсичності м'яса, отриманого від птиці, хворої на еймеріоз.

Матеріали і методи. Основним об'єктом досліджень було м'ясо курей, хворих на еймеріоз, та м'ясо здорової птиці.

Для дослідження на токсичність було відібрано м'ясо від тушок хворої птиці з ознаками виснаження (1-ша проба), м'ясо від тушок хворої птиці без ознак виснаження (2-га проба), та м'ясо від клінічно здорової птиці (3-тя проба).

Вивчення визначення токсичності м'яса проводили за допомогою сухої культури колподи (Colpoda steinii ) за «Методикою із застосування культури колподи сухої для токсикологічних досліджень м'яса і м'ясопродуктів від тварин та птиці» (2002) [4]. Виготовленння сухої культури колоди здійснювалося згідно з вимогами нормативної документації ТУ У 46.15.243-97 зі стандартоної комерційної серії культури колоди штамм П-1. Метод заснований на вилученні 3 досліджуваних продуктів різних фракцій токсичних речовин дистильованою водою та подальшою дією цих екстрактів на культуру інфузоpiï Colpoda Steinii.

Результати досліджень. У процесі дослідження тушок, птиці хворої на еймеріоз із ознаками виснаження, ми встановили, що у $80 \%$ проб м'яса загибель колпод наступала упродовж трьох годин. Це вказує на те, що м'ясо, отримане від тушок із ознаками виснаження птиці, хворої на еймеріоз, токсичне. Отже, таке м'ясо направляється на технічну утилізацію. 


\section{1. Показники токсичності м'яса, отриманого від тушок із ознаками виснаження птиці,} хворої на еймеріоз

\begin{tabular}{|c|c|c|}
\hline № зразка & Показники & Рівень токсичності \\
\hline 1 & $\begin{array}{c}\text { упродовж трьох годин загибель менше 90\% колпод та } \\
\text { інтенсивність росту становила менше 90\% }\end{array}$ & слаботоксичний \\
\hline 2 & загибель колпод наступала упродовж трьох годин & токсичний \\
\hline 3 & загибель колпод наступала упродовж трьох годин & токсичний \\
\hline 4 & загибель колпод наступала упродовж трьох годин & токсичний \\
\hline 5 & загибель колпод наступала упродовж трьох годин & токсичний \\
\hline
\end{tabular}

2. Показники токсичності м'яса, отриманого від тушок без ознак виснаження птиці, хворої на еймеріоз

\begin{tabular}{|c|c|c|}
\hline № проб & Показники & Рівень токсичності \\
\hline 1 & $\begin{array}{c}\text { упродовж трьох годин гинуло менше 90 \% колпод та } \\
\text { інтенсивність росту становила менше 90\% }\end{array}$ & не токсичний \\
\hline 2 & ті ж & слаботоксичний \\
\hline 3 & ті ж & слаботоксичний \\
\hline 4 & ті ж & слаботоксичний \\
\hline 5 & ті ж & слаботоксичний \\
\hline
\end{tabular}

3. Показники токсичності м'яса, отриманого від тушок без ознак виснаження птиці, хворої на еймеріоз, після проварювання

\begin{tabular}{|c|c|c|}
\hline № проб & Показники & Рівень токсичності \\
\hline 1 & $\begin{array}{c}\text { упродовж трьох годин колподи залишалися рухливи- } \\
\text { ми, а їх інтенсивність росту становила 90\% }\end{array}$ & не токсичний \\
\hline 2 & ті ж & не токсичний \\
\hline 3 & ті ж & не токсичний \\
\hline 4 & ті ж & не токсичний \\
\hline 5 & ті ж & не токсичний \\
\hline
\end{tabular}

Досліджуючи м'ясо, отримане від тушок без ознак виснаження птиці, хворої на еймеріоз, нами були отримані результати, які вказують, що в усіх пробах інтенсивність загибелі колпод складала менше $90 \%$. Інтенсивність їх росту також була нижче $90 \%$. Враховуючи отримані дані, ми бачимо, що м'ясо слаботоксичне (табл. 2).

Проби м'яса, отримані від тушок здорової птиці, були не токсичними, в усіх пробах упродовж трьох годин колподи залишалися рухливими, а їх інтенсивність росту сягала $90 \%$.

Задля інактивації токсинів у м'ясі птиці ми проварили упродовж трьох годин проби м'яса, отриманого від тушок без ознак виснаження

\section{БІБЛІОГРАФІЯ}

1. Апатенко В. М., Горжеев В. М. Эмерджентные болезни и паразитоценозы // Збірник наукових праць Луганского НАУ: Ветеринарні науки. 2003. - № 27/39. - С. 10-15.

2. Епізоотичний стан птахівництва в Україні / О. Вержиховський, Ю. Колос, В. Титаренко [та ін.] // Ветеринарна медицина України. - 2007. №6. - C. 8-10.

3. Ковбасенко В. М., Воробей А. М. Экспрессметод определения токсичности пищевых проду- птиці, хворої на еймеріоз, а потім визначили їх токсичність.

Отже, після проварювання м'яса зі слабим рівнем токсичності проходить повне виведення токсинів, і воно стає придатним для споживання.

Висновки:

1. М'ясо, отримане від тушок із ознаками виснаження птиці, хворої на еймеріоз, - токсичне.

2. М'ясо, отримане від тушок без ознак виснаження птиці, хворої на еймеріоз, - слаботоксичне.

3. У разі проварювання тушок птиці зі слабким рівнем токсичності упродовж трьох годин м'ясо стає безпечним для споживання.

ктов с использованием инфузории-колподостении / Ветеринария в птицеводстве. - С.-Пб., 2002. №4. - C. 26-28.

4. Позняковский В. М. Экспертиза мяса и м'ясопродуктов. - Новосибирск. - 2002. - 526 с.

5. Практикум по ветеринарно-санитарной экспертизе с основами технологии продуктов животноводства [Електронний ресурс]: Под ред. В. А. Макарова. - Режим доступу до документа: http://vetfac.narod.ru/vse.htm. 